\title{
External Risk Effect in Infrastructure Design-Build Projects with Lump Sum Contracts
}

\author{
Ari Wibowo, Rosalendro Eddy Nugroho, Bambang Purwoko Kusumo Bintoro
}

\begin{abstract}
The increase of fast completion and cost certainty demands of construction projects were encouraging the Provincial Government of DKI Jakarta to use the design-build as a project delivery system. However, the design-build project experienced several constraints. This research aimed to determine the effect of external risks (consist of land acquisition, utility disruption, and third-party risk) on project performance of infrastructure design-build projects with a lump-sum contract system. A mix-method of quantitative and qualitative approaches used in this research, with data collected by using a questionnaire, interview, and documentation study. The questionnaire sent to contractors involved in design-build contracts for the 2015-2018 period, as many as 78 respondents from 39 projects. Fifty responses received within the stipulated time. Quantitative data analysis carried out by using the Structural Equation Model (SEM) based on Partial Least Square (PLS) using SmartPLS and qualitative data used as supporting data. The research findings were as follows. First, land acquisition, utility disruption, and third-party risk had no significant effect on project time performance. Simultaneously, the external risk contributed $11.7 \%$ of the time performance variable. Second, the utility disruption and third-party risk requests had a significant negative effect on cost performance, while the land acquisition risk did not have a significant effect on cost performance. Simultaneously, the external risks contributed to $39.3 \%$ of the cost performance. Third, time performance has a positive and significant effect on cost performance. Fourth, there was inadequate and inaccurate information related to the existence of the external risk, as well as an inadequate allocation of risk handling costs. Risk identification was vital. Furthermore, working schedules had to synchronize to the risk management schedule in such a way that the effectiveness and efficiency of the work could be maximized by considering all aspects. The response to risk could differ from project to project even between the same types of construction projects. The risk response determined by considering their impact on the project's time and cost performance.
\end{abstract}

Keywords: design-build, external risk, lump sum contract, project performance.

Revised Manuscript Received on February 05, 2020.

* Correspondence Author

Ari Wibowo*, Civil Engineering Master Program, Mercu Buana University, Jakarta, Indonesia. E-mail: arijakon88@gmail.com

Rosalendro Eddy Nugroho, Civil Engineering Master Program, Mercu Buana University, Jakarta, Indonesia. E-mail: rosalendro.eddy@mercubuana.ac.id

Bambang Purwoko Kusumo Bintoro, Graduate School of Business, Bakrie University, Jakarta, Indonesia. E-mail: kusumo.bintoro@bakrie.ac.id

(C) The Authors. Published by Blue Eyes Intelligence Engineering and Sciences Publication (BEIESP). This is an open access article under the CC BY-NC-ND license (http://creativecommons.org/licenses/by-nc-nd/4.0/)

\section{INTRODUCTION}

The demands of fast completion and cost certainty of construction projects are increasing. It encourages the Provincial Government of DKI Jakarta, Republic of Indonesia, to use the design-build as a project delivery system. Design-build is a project delivery system that integrates design and construction services into a single contract.

A study of 351 projects in 37 states of the USA showed some benefits of the design-build method compared to the traditional method. In this regard, the design-build method gives a $6 \%$ benefit to the total project cost, the cost overrun due to work changes were reduced by $5.2 \%$, and the total project completion time that $33 \%$ faster than traditional methods [1].

However, the design-build project's implementation in DKI Jakarta Province has shown non-optimal results. It indicated several delays in projects' completion, both in the construction of buildings and civil buildings (infrastructure). For instance, from a total of 23 design-build construction works initiated by the Education Agency of DKI Jakarta Province, there was 17 project completion that delayed in 2017 (73.9\%). Similar delays also occurred in infrastructure construction projects. In this case, as many as $13(81.25 \%)$ infrastructure design-build projects in 2015-2017 having late completion of work, as depicted in Table-I.

Table- I: Duration of Delay in Infrastructure Design-Build Projects in DKI Jakarta 2015-2017

\begin{tabular}{|c|c|c|}
\hline No. & Project Name & $\begin{array}{c}\text { Duration of } \\
\text { Delay (Days) }\end{array}$ \\
\hline 1 & JLKB Tendean & 0 \\
\hline 2 & JLKB Santa & 90 \\
\hline 3 & JKB Trunojoyo & 59 \\
\hline 4 & JLKB Taman Puring & 59 \\
\hline 5 & JLKB Kemayoran & 59 \\
\hline 6 & JLKB Seskoal & 59 \\
\hline 7 & JLKB Cipulir & 120 \\
\hline 8 & JLKB Ciledug & 150 \\
\hline 9 & Fly Over Kuningan & 0 \\
\hline 10 & Fly Over Permata Hijau & 0 \\
\hline 11 & Fly Over Pancoran & 105 \\
\hline 12 & Fly Over Cipinang & 60 \\
\hline 13 & Fly Over Bintaro & 60 \\
\hline 14 & Underpass Pondok Indah & 30 \\
\hline 15 & Underpass Matraman & 90 \\
\hline
\end{tabular}




\section{External Risk Effect in Infrastructure Design-Build Projects with Lump Sum Contracts}

\begin{tabular}{|l|l|l|}
\hline 16 & Underpass Kuningan & 15 \\
\hline
\end{tabular}

Source: Archive Project

Furthermore, an initial survey conducted to all projects' heads in 2017 (6 projects) to find out the factors causing delays in the design-build project in DKI Jakarta Province. Based on the survey, the dominant factor that caused the delay in project completion were: (1) existing land condition; (2) administrative issues; (3) requests from third parties; and (4) construction design.

Delay in project completion potentially causes project cost overruns, whereas in contracts with lump sum types, all risks, including additional costs, are the contractor's responsibility. Therefore, this research aims to find out the risk effect on project performance of design-build projects with a lump-sum contract system.

\section{THEORIES AND CONCEPTS}

\section{A. Design-Build Project}

According to PMBOK (2017), a project is a temporary endeavor undertaken to create a unique product, service, or result. Fulfillment of project objectives may produce one or more of the following deliverables: (1) a product, could be either the component of another item, an enhancement or correction to an item, or a new end item in itself; (2) a service or capability to perform a service; (3) a result, for instance, as an outcome or document; and (4) unique combination of one or more products, services, or results [2].

Construction projects have several characteristics. First, projects are unique. There are no identical but similar projects. They are temporary, and always involve different groups. Second, projects required resources (for instance, labor, money, equipment, methods, and materials). Third, the organization. Each organization has a variety of objectives in which several individuals with specialized expertise are involved [3].

A construction project that uses the design-build method as its deliverable system has some differences from the traditional method. In a design-bid-build method, the owner contract professional for designing, and then contracts a contractor to build the project with that design [4] Meanwhile, in a design-build method, both design and construction service is the contractor's responsibility. It makes the contract system in a design-build method quite different from traditional contracts [5].

Several possible advantages of using the design-build method are as follows: 1) time savings, 2) cost savings, 3) one point of contact (one-stop shopping), 4) fewer change orders, and 5) reduced risk to project owner. Meanwhile, the possible disadvantages of the design-build method are as follows: 1) loss of control of project design, 2) less project oversight/control of quality, and 3) suitability of design-build team [4].

\section{B. Risk Management}

Kerzner (2003) defines risk event as "a discrete event that, if occurring, would have a positive or negative effect on project measures" [6]. The construction project has a high potential risk compared to other projects. It is unlike other industries, more complicated and challenging to manage because it requires special skills and techniques. For managing risks, there must be different priorities for the risks [3].

According to PMBOK (2017), project risk management includes risk management planning, identification, analysis, response planning, response implementation, and monitoring risk on a project [2]. Project risk management aims to improve project performance by systematically identifying and assessing risks, developing strategies to prevent or avoid them, and to maximize opportunities [6].

Risk and uncertainty management has a vital role in project management. Therefore, risk management is not an optional activity. Risk management is crucial for the success of project management, so it needs to be applied to all parts of the project and become part of the project's operational plans and documents. In this way, risk management becomes an integral part of every aspect of project management in every phase and process group [7].

Generally, risk divided into two categories, internal and external risks. An internal risk is a risk that comes from the company or the project itself, for instance, costs, productivity, contracts, completion times, and others. Whereas, external risks do not come from the company or project, for instance, political conditions, regulations, and others [8].

\section{Project Performance}

Project performance has triple constraints, namely, cost/budgeting constraints, schedule/time, and quality. Meanwhile, according to Kerzner (2006), project management categorized as successful if the project has achieved the project objectives, the allocated times, budgeted costs, at the level of performance/technology stipulated, received by the customer and used the specified resources effectively and efficiently [3].

Several keys concepts generally used in project management are as follows: (1) project measures, are the critical criteria in a project (i.e., project time, project quality, and project cost); (2) project scope, is the target state of the project in terms of project measures; and (3) project ultimacy, is the ultimate state of the project in terms of project measures [5].

\section{Lump Sum Contract}

Based on Presidential Regulation Number 16 of 2018 on Procurement of Government Goods/Services, there are several types of contracts in construction. First, lump-sum contract or fixed price. It is a contract with fixed project scope and price, within the following condition: all risks borne to the contractor, result-oriented, and payment based on product or output phase. Second, the unit price contract is a contract with a fixed unit price for each unit or element of work with specific technical specifications of work within the stipulated deadline. In a unit price contract, the volume or quantity of work estimated at the contract assignment, payment based on the volume of the work measurement result, and the final value of the contract determined after all work completed. The other types are combination of fixed-price and unit-price contract, turnkey, and umbrella contract [9]. 


\section{E. Conceptual Model}

In this research, the conceptual model developed based on several categories of external risks and project performance (also known as exogenous latent variables). Risks are consisting of utility disruption risk, land-acquisition risk, and third-party risk. On the other side, project performance consists of time performance and cost performance.

The variables, dimensions, and indicators of this research are as depicted in Table-II. The description of each manifest variable as presented in path diagrams for each construct shown in Figure 1.

Table- II: Research Variables, Dimensions, and Indicators

\begin{tabular}{|c|c|c|c|c|}
\hline Variable & Definition & Dimension & Indicator & Item \\
\hline \multirow{6}{*}{$\begin{array}{l}\text { Utility } \\
\text { disruption } \\
\text { risk }\end{array}$} & \multirow{6}{*}{$\begin{array}{l}\text { The existence of the } \\
\text { utility system at the } \\
\text { project site that was not } \\
\text { detected before and } \\
\text { disrupted the project } \\
\text { implementation [8]. }\end{array}$} & $\begin{array}{l}\text { Implementation of } \\
\text { work methods }\end{array}$ & $\begin{array}{l}\text { The working methods implementation level due to utility } \\
\text { system disruption. }\end{array}$ & X1_6 \\
\hline & & $\begin{array}{l}\text { Tools' } \\
\text { operationalization }\end{array}$ & $\begin{array}{l}\text { The tools' operationalization level due to utility system } \\
\text { disruption. }\end{array}$ & $\mathrm{X} 1 \_7$ \\
\hline & & Material acceptance & $\begin{array}{l}\text { The material acceptance level due to utility system } \\
\text { disruption. }\end{array}$ & $\mathrm{X} 1 \_8$ \\
\hline & & $\begin{array}{l}\text { Work } \\
\text { implementation }\end{array}$ & $\begin{array}{l}\text { The work implementation level due to utility system } \\
\text { disruption. }\end{array}$ & X1_9 \\
\hline & & \multirow[t]{2}{*}{ Risk probability } & Frequency of utility disruption. & $\mathrm{X} 1 \_10$ \\
\hline & & & The time occurrence of utility disruption risk. & $\mathrm{X} 1 \_11$ \\
\hline \multirow{5}{*}{$\begin{array}{l}\text { Land- } \\
\text { acquisition } \\
\text { risk }\end{array}$} & \multirow{5}{*}{$\begin{array}{l}\text { Unfinished land } \\
\text { acquisition though the } \\
\text { project is already } \\
\text { underway. }\end{array}$} & $\begin{array}{l}\text { Implementation of } \\
\text { work methods }\end{array}$ & $\begin{array}{l}\text { The working methods implementation level due to } \\
\text { unfinished land-acquisition. }\end{array}$ & $\mathrm{X} 2 \_6$ \\
\hline & & $\begin{array}{l}\text { Tools' } \\
\text { operationalization }\end{array}$ & $\begin{array}{l}\text { The tools' operationalization level due to unfinished } \\
\text { land-acquisition. }\end{array}$ & $\mathrm{X} 2 \_7$ \\
\hline & & $\begin{array}{l}\text { Work } \\
\text { implementation }\end{array}$ & $\begin{array}{l}\text { The work implementation level due to unfinished } \\
\text { land-acquisition. }\end{array}$ & X2_9 \\
\hline & & \multirow[t]{2}{*}{ Risk probability } & Frequency of land-acquisition risk. & $\mathrm{X} 2 \_10$ \\
\hline & & & The time occurrence of land-acquisition risk. & $\mathrm{X} 2 \_11$ \\
\hline \multirow[t]{6}{*}{$\begin{array}{l}\text { Third-party } \\
\text { risk }\end{array}$} & \multirow{6}{*}{$\begin{array}{l}\text { The changing of the } \\
\text { scope of work due to the } \\
\text { third-party request. }\end{array}$} & $\begin{array}{l}\text { Implementation of } \\
\text { work methods }\end{array}$ & $\begin{array}{l}\text { The working methods implementation level due to the } \\
\text { third-party request. }\end{array}$ & X3_6 \\
\hline & & $\begin{array}{l}\text { Tools' } \\
\text { operationalization }\end{array}$ & $\begin{array}{l}\text { The tools' operationalization level due to unfinished } \\
\text { land-acquisition. }\end{array}$ & X3_7 \\
\hline & & Material acceptance & $\begin{array}{l}\text { The material acceptance level due to the third-party } \\
\text { request. }\end{array}$ & X3_8 \\
\hline & & $\begin{array}{l}\text { Work } \\
\text { implementation }\end{array}$ & $\begin{array}{l}\text { The work implementation level due to the third-party } \\
\text { request. }\end{array}$ & X3_9 \\
\hline & & \multirow[t]{2}{*}{ Risk probability } & Frequency of the third-party risk & X3_10 \\
\hline & & & The time occurrence of the third-party risk. & X3_11 \\
\hline \multirow{10}{*}{$\begin{array}{l}\text { Time } \\
\text { performance }\end{array}$} & \multirow{10}{*}{$\begin{array}{l}\text { The level of project } \\
\text { performance based on the } \\
\text { actual time compared to } \\
\text { project planning [10]. }\end{array}$} & Planning & The actual time of the initial survey and measurement. & Y1_3 \\
\hline & & \multirow[t]{9}{*}{ Implementation } & The actual time of the working method's determination. & Y1_4 \\
\hline & & & The actual time of tools' determination and arrival. & Y1_5 \\
\hline & & & $\begin{array}{l}\text { The actual time of the material's determination and } \\
\text { arrival. }\end{array}$ & Y1_6 \\
\hline & & & $\begin{array}{l}\text { The actual time of the workers' determination and } \\
\text { arrival. }\end{array}$ & Y1_7 \\
\hline & & & $\begin{array}{l}\text { The actual time of the subcontractor's determination and } \\
\text { arrival. }\end{array}$ & Y1_8 \\
\hline & & & The actual time of the tools' utilization & Y1_9 \\
\hline & & & $\begin{array}{l}\text { The actual time of the completion of works by the } \\
\text { workers. }\end{array}$ & Y1_10 \\
\hline & & & $\begin{array}{l}\text { The actual time of the completion of works by the } \\
\text { subcontractor. }\end{array}$ & Y1_11 \\
\hline & & & $\begin{array}{l}\text { The actual time of the self-managed work completion } \\
\text { time. }\end{array}$ & Y1_12 \\
\hline \multirow{7}{*}{$\begin{array}{l}\text { Cost } \\
\text { performance }\end{array}$} & \multirow{7}{*}{$\begin{array}{l}\text { The level of project } \\
\text { performance based on the } \\
\text { actual cost compared to } \\
\text { project planning [11]. }\end{array}$} & \multirow[t]{7}{*}{ Direct cost } & The actual volume of material. & Y2_1 \\
\hline & & & The actual cost of the material's unit price. & Y2_2 \\
\hline & & & The actual volume of tools. & Y2_3 \\
\hline & & & The actual cost of the tools' unit price. & Y2_4 \\
\hline & & & The actual volume of workers. & Y2_5 \\
\hline & & & The actual cost of the workers' unit price. & Y2_6 \\
\hline & & & The actual volume of subcontractor's works. & Y2_7 \\
\hline
\end{tabular}


External Risk Effect in Infrastructure Design-Build Projects with Lump Sum Contracts

\begin{tabular}{|c|c|c|c|c|}
\hline Variable & Definition & Dimension & Indicator & Item \\
\hline & & & The actual cost of the subcontractor works' unit price. & Y2_8 \\
\hline & & \multirow[t]{4}{*}{ Overhead cost } & The actual volume of employees. & Y2_9 \\
\hline & & & The actual cost of the employees' unit price. & Y2_10 \\
\hline & & & The actual volume of general cost. & Y2_11 \\
\hline & & & The actual amount of the general cost. & Y2_12 \\
\hline
\end{tabular}

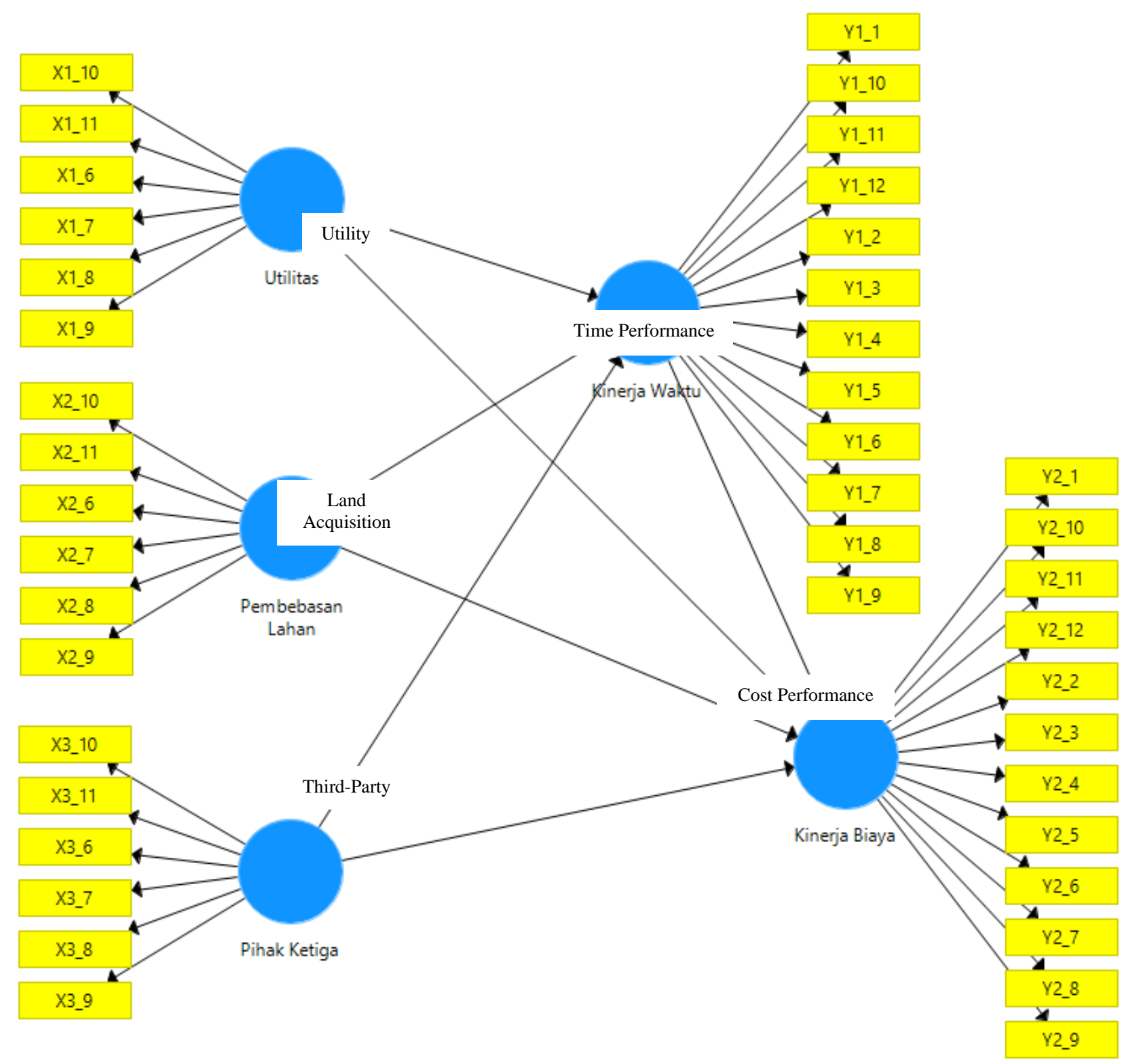

Fig. 1. Conceptual Model

\section{RESEARCH METHOD}

This research used a mix-method of a quantitative and qualitative approach. The research stages are as follows. First, identify problems that occur in construction projects, especially in design projects with a fixed price contract system. Second, conduct a theoretical study that used to clarify the problem, formulate hypotheses, and research instrumentation. Third, quantitative data collected by using a questionnaire and qualitative data collected by interviews, questionnaires, documentation studies, and observations. Fourth, the data collected, both quantitative and qualitative, are then analyzed. Fifth, the presentation of quantitative and qualitative data analysis data, as well as the discussion of research results. Sixth, research reports preparation.

Data collection was conducted in April-July 2019. The questionnaire was sent to contractors (excluding consultant and owner) that involved in design-build contracts for the 2015-2018 period, as many as 78 respondents from 39 projects. Fifty responses received within the stipulated time. Quantitative data analysis carried out by using the Structural Equation Model (SEM) based on Partial Least Square (PLS) using SmartPLS. Qualitative data used as supporting data. Data analysis, both quantitative and qualitative, was done in sequential steps, as follows: data collection, data reduction, data display, and conclusion.

Published By:

Retrieval Number: C5533029320/2020@BEIESP 


\section{RESEARCH FINDINGS AND DISCUSSION}

\section{A. Demography of the Respondents}

Based on the completed questionnaire sets, the demography of the respondents presented in Table-III. Majority of the respondents, or $64 \%$, had a bachelor's degree background and 32\% with a graduate degree. Also, 62\% of respondents had working experiences for more than 15 years in handling construction projects, with minimum working experience is 5 to 10 years (12\%).

Table- III. The Respondents' Characteristic

\begin{tabular}{|l|c|c|c|}
\hline \multicolumn{1}{|c|}{ Characteristic } & Frequency & Percentage & $\begin{array}{c}\text { Cumulative } \\
\text { Percentage }\end{array}$ \\
\hline Education Level & & & \\
High School & 2 & 4 & 4 \\
Bachelor & 32 & 64 & 68 \\
Graduate & 16 & 32 & 100 \\
Postgraduate & 0 & 0 & 100 \\
\hline
\end{tabular}

\begin{tabular}{|l|c|c|c|}
\hline Working Experience & & & \\
$<2$ years & 0 & 0 & 0 \\
2-5 years & 6 & 0 & 0 \\
5-10 years & 13 & 26 & 12 \\
$10-15$ years & 31 & 62 & 38 \\
$>15$ years & & 100 \\
\hline
\end{tabular}

Source: Primary Data (Calculated), 2019

\section{B. Model Evaluation/Analysis}

The unidimensionality of each construct tested by looking at the convergent validity of each construct indicator. Manifest variables with external loading 0.5 or higher are considered acceptable, and manifest variables with loading values less than 0.5 excluded from the model. Thus, all constructs have met the validity requirements, as shown in Fig. 2.

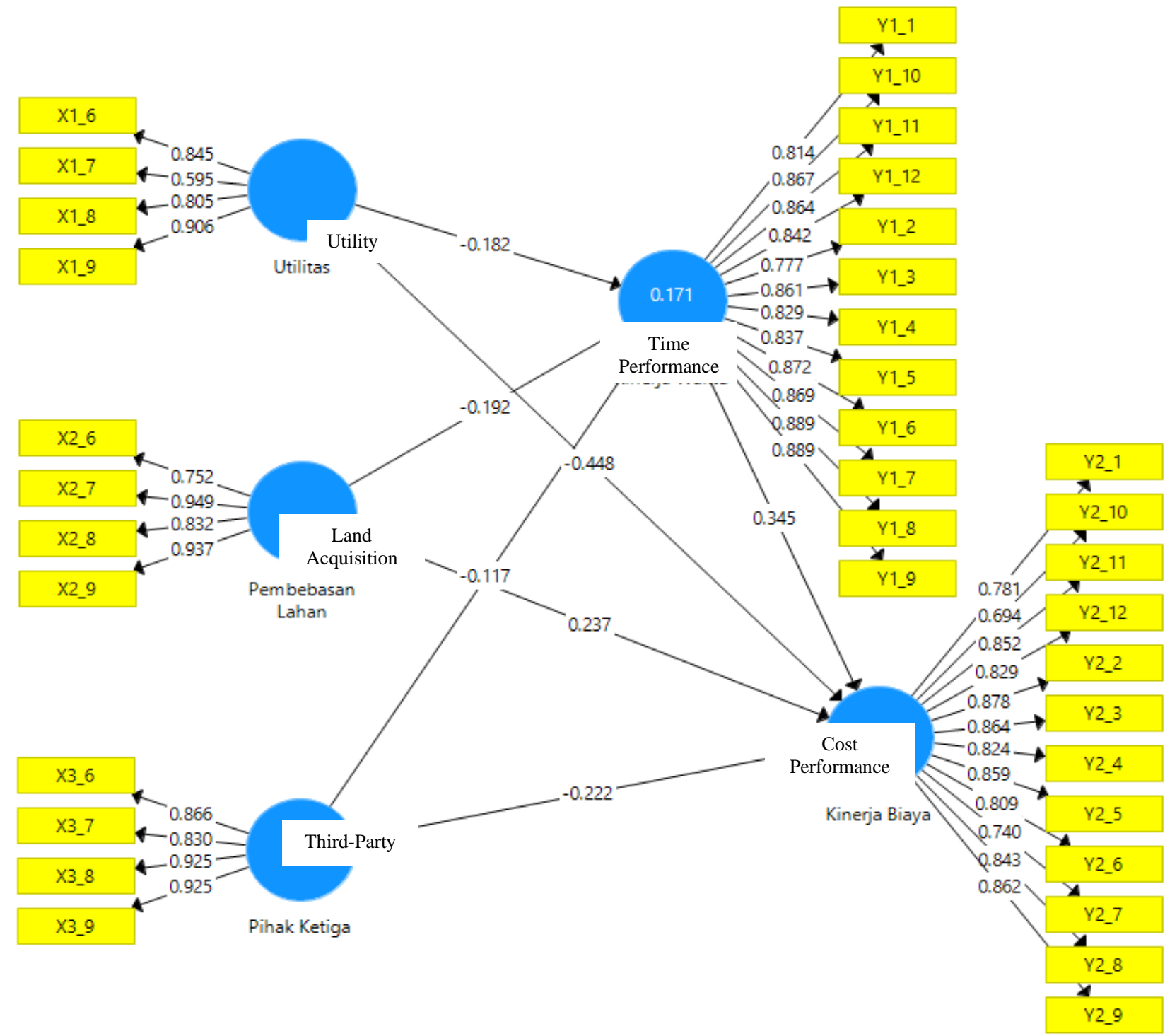

Fig. 2. Outer Loading Re-estimate

The next step is to evaluate the outer model using two criteria, namely discriminant validity and composite reliability. Based on the Average Variance Extracted (AVE) value, all constructs have an AVE root value higher than the correlation between constructs and other constructs. So, it concluded that all constructs had met the validity requirements. Furthermore, based on the analysis results, the value of Cronbach's Alpha and Composite Reliability is above 0.80; thus, each construct is very reliable.

Published By:

Retrieval Number: C5533029320/2020@BEIESP

DOI: 10.35940/ijeat.C5533.029320

Journal Website: www.ijeat.org

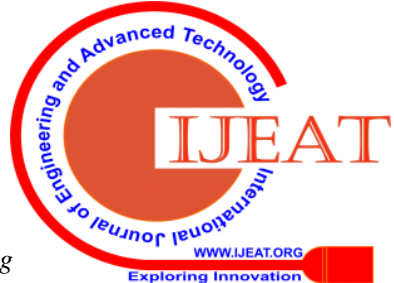




\section{External Risk Effect in Infrastructure Design-Build Projects with Lump Sum Contracts}

The inner model evaluated by looking at the value of $\mathrm{R}$ Square. R Square Adjusted Time Performance value of 0.117 means that the influence of the Utility Disruption Risk, Land Acquisition Risk, and Third-Party Risk to Time Performance is $11.7 \%$.

The value of the effect size of Utility Disruption Risk (0.024) and Land Acquisition Risk (0.026) are classified as weak, while Third-Party Risk (0.011) is feeble or has no effect.

Table- IV. The R Square Value

\begin{tabular}{|l|c|c|}
\hline & R Square & R Square Adjusted \\
\hline Cost Performance & 0,443 & 0,393 \\
\hline Time Performance & 0,171 & 0,117 \\
\hline
\end{tabular}

Source: Primary Data (Calculated), 2019

The value of $\mathrm{R}$ Square Adjusted Cost Performance of 0.393 means that the influence of the Utility Disruption Risk, Land Acquisition Risk, Third-Party Risk, and Time on Cost Performance is $39.3 \%$. The value of the effect size of Utility Disruption Risk (0.209) and Time (0.177) are classified as moderate, while Land Acquisition Risk (0.057) and Third-Party Risk (0.057) are relatively weak.

Table- V. The f Square Value

\begin{tabular}{|l|c|c|}
\hline & $\begin{array}{c}\text { Cost } \\
\text { Performance }\end{array}$ & $\begin{array}{c}\text { Time } \\
\text { Performance }\end{array}$ \\
\hline Cost Performance & & \\
\hline Time Performance & 0,177 & \\
\hline Land Acquisitio & 0,057 & 0,026 \\
\hline Pihak Ketiga & 0,057 & 0,011 \\
\hline Utilitas & 0,209 & 0,024 \\
\hline
\end{tabular}

Source: Primary Data (Calculated), 2019

\section{Statistical Description of Research Variables}

The lowest effect of utility disruption risk found in material acceptance with the highest average value of 3.12 . The highest effect found in the implementation of working methods with the smallest average value of 2.70. Overall, the average value of the risk utility disruption variable is 2.91. Based on Table-VI, it could be concluded that the utility disruption risk that had not been overcome caused partial or half of working methods, operational tools, materials, and work implementation by workers that could not be carried out.

Table- VI. The Variable Profile of Utility Disruption Risk

\begin{tabular}{|l|c|c|}
\hline \multicolumn{1}{|c|}{ Indicators } & Item & Average \\
\hline $\begin{array}{l}\text { The working methods implementation } \\
\text { level due to utility system disruption. }\end{array}$ & X1_6 & 2.70 \\
\hline $\begin{array}{l}\text { The tools' operationalization level due } \\
\text { to utility system disruption. }\end{array}$ & X1_7 & 2.96 \\
\hline $\begin{array}{l}\text { The material acceptance level due to } \\
\text { utility system disruption. }\end{array}$ & X1_8 & 3.12 \\
\hline $\begin{array}{l}\text { The work implementation level due to } \\
\text { utility system disruption. }\end{array}$ & X1_9 & 2.84 \\
\hline \multicolumn{2}{|c|}{ Variable Average } & 2.91 \\
\hline
\end{tabular}

Source: Primary Data (Calculated), 2019

Table-VII shows that the lowest effect of land acquisition risk found in material acceptance, while the highest effect found in the work implementation by workers. Overall, the land acquisition risk that had not been overcome caused partial or half of working methods, operational tools, materials, and work

Table- VII. The Variable Profile of Land Acquisition Risk

\begin{tabular}{|l|c|c|}
\hline \multicolumn{1}{|c|}{ Indicators } & Item & Average \\
\hline $\begin{array}{l}\text { The working methods implementation } \\
\text { level due to unfinished } \\
\text { land-acquisition. }\end{array}$ & X2_6 & 2.60 \\
\hline $\begin{array}{l}\text { The tools' operationalization level due } \\
\text { to unfinished land-acquisition. }\end{array}$ & X2_7 & 2.56 \\
\hline $\begin{array}{l}\text { The material acceptance level due to } \\
\text { unfinished land-acquisition. }\end{array}$ & X2_8 & 2.78 \\
\hline $\begin{array}{l}\text { The work implementation level due to } \\
\text { unfinished land-acquisition. }\end{array}$ & X2_9 & 2.54 \\
\hline \multicolumn{2}{|c|}{ Variable Average } & 2.62 \\
\hline
\end{tabular}

Source: Primary Data (Calculated), 2019

The lowest effect of third-party risk found in tools operationalization, while the highest effect found in the material acceptance and work implementation by workers. Overall, the third-party risk that had not been overcome caused partial or half of working methods, operational tools, materials, and work implementation by workers that could not be carried out.

Table- VIII The Variable Profile of Third-Party Risk

\begin{tabular}{|l|c|c|}
\hline \multicolumn{1}{|c|}{ Indicators } & Item & Average \\
\hline $\begin{array}{l}\text { The working methods implementation } \\
\text { level due to the third-party request. }\end{array}$ & X3_6 & 3.14 \\
\hline $\begin{array}{l}\text { The tools' operationalization level due } \\
\text { to unfinished land-acquisition. }\end{array}$ & X3_7 & 3.26 \\
\hline $\begin{array}{l}\text { The material acceptance level due to } \\
\text { the third-party request. }\end{array}$ & X3_8 & 3.10 \\
\hline $\begin{array}{l}\text { The work implementation level due to } \\
\text { the third-party request. }\end{array}$ & X3_9 & 3.10 \\
\hline \multicolumn{2}{|c|}{ Variable Average } & 3.15 \\
\hline
\end{tabular}

Source: Primary Data (Calculated), 2019

Description of time performance variable aims to determine the level of the time performance on design-build projects with a fixed price contract system. Table-IX shows the highest average value found on the completion of works by the subcontractor, while the lowest value is on the actual time of the material's determination and arrival. Overall, the average value of the time performance variable is 3.61 . It could be concluded that the average time delayed was three weeks.

Table- IX The Variable Profile of Time Performance

\begin{tabular}{|l|c|c|}
\hline \multicolumn{1}{|c|}{ Indicators } & Item & Average \\
\hline $\begin{array}{l}\text { The actual time of the initial survey and } \\
\text { measurement. }\end{array}$ & Y1_1 & 3.40 \\
\hline $\begin{array}{l}\text { The actual time of the land } \\
\text { measurement. }\end{array}$ & Y1_2 & 3.40 \\
\hline $\begin{array}{l}\text { The actual time of the initial survey and } \\
\text { measurement. }\end{array}$ & Y1_3 & 3.84 \\
\hline
\end{tabular}




\begin{tabular}{|c|c|c|}
\hline Indicators & Item & Average \\
\hline $\begin{array}{l}\text { The actual time of the working } \\
\text { method's determination. }\end{array}$ & Y1_4 & 3.62 \\
\hline $\begin{array}{l}\text { The actual time of tools' determination } \\
\text { and arrival. }\end{array}$ & Y1_5 & 3.56 \\
\hline $\begin{array}{l}\text { The actual time of the material's } \\
\text { determination and arrival. }\end{array}$ & Y1_6 & 3.36 \\
\hline $\begin{array}{l}\text { The actual time of the workers' } \\
\text { determination and arrival. }\end{array}$ & Y1_7 & 3.38 \\
\hline $\begin{array}{l}\text { The actual time of the subcontractor's } \\
\text { determination and arrival. }\end{array}$ & Y1_8 & 3.40 \\
\hline The actual time of the tools' utilization & Y1_9 & 3.78 \\
\hline $\begin{array}{l}\text { The actual time of the completion of } \\
\text { works by the workers. }\end{array}$ & $\begin{array}{c}\mathrm{Y} 1 \_1 \\
0\end{array}$ & 3.76 \\
\hline $\begin{array}{l}\text { The actual time of the completion of } \\
\text { works by the subcontractor. }\end{array}$ & $\begin{array}{c}\mathrm{Y} 1 \_1 \\
1\end{array}$ & 3.90 \\
\hline $\begin{array}{l}\text { The actual time of the self-managed } \\
\text { work completion time. }\end{array}$ & $\begin{array}{c}\text { Y1_1 } \\
2\end{array}$ & 3.86 \\
\hline \multicolumn{2}{|l|}{ Variable Average } & 3.61 \\
\hline
\end{tabular}

Source: Primary Data (Calculated), 2019

Furthermore, the description of the cost performance variable shown in Table-X. The highest average value found on the actual volume of tools, while the lowest value is on the actual volume of subcontractor's works, the actual cost of the subcontractor works' unit price, and the actual cost of the employees' unit price. Overall, the average value of the cost performance variable is 2.74 . It could be concluded that the average increase in the volume/cost of the project was in the range of $2.5-5.0 \%$.

Table- X The Variable Profile of Cost Performance

\begin{tabular}{|l|c|c|}
\hline \multicolumn{1}{|c|}{ Indicators } & Item & Average \\
\hline The actual volume of material. & Y2_1 & 2.54 \\
\hline $\begin{array}{l}\text { The actual cost of the material's unit } \\
\text { price. }\end{array}$ & Y2_2 & 2.64 \\
\hline The actual volume of tools. & Y2_3 & 3.14 \\
\hline The actual cost of the tools' unit price. & Y2_4 & 2.84 \\
\hline The actual volume of workers. & Y2_5 & 2.92 \\
\hline $\begin{array}{l}\text { The actual cost of the workers' unit } \\
\text { price. }\end{array}$ & Y2_6 & 2.52 \\
\hline $\begin{array}{l}\text { The actual volume of subcontractor's } \\
\text { works. }\end{array}$ & Y2_7 & 2.48 \\
\hline $\begin{array}{l}\text { The actual cost of the subcontractor } \\
\text { works' unit price. }\end{array}$ & Y2_8 & 2.48 \\
\hline The actual volume of employees. & Y2_9 & 2.82 \\
\hline $\begin{array}{l}\text { The actual cost of the employees' unit } \\
\text { price. }\end{array}$ & Y2_10 & 2.48 \\
\hline The actual volume of general cost. & Y2_11 & 3.00 \\
\hline The actual amount of the general cost. & Y2_12 & 3.02 \\
\hline \multicolumn{2}{|c|}{ Variable Average } & 2.74 \\
\hline
\end{tabular}

Source: Primary Data (Calculated), 2019

\section{Hypothesis Test Result}

The effect of each variable on project performance as depicted in Table-XI. So, it could be concluded that three research hypotheses accepted from seven proposed hypotheses, namely: Hypothesis IV, Hypothesis VI, and Hypothesis VII.

Table- XI The Research Hypothesis

\begin{tabular}{|c|c|c|c|c|c|}
\hline \multicolumn{2}{|r|}{ Research Hypothesis } & Coefficient & T Statistic & P Value & Note \\
\hline $\mathrm{H} \mathrm{I}$ & $\begin{array}{l}\text { There is a significant negative effect of the utility disruption risk on the } \\
\text { time performance of a design project with a fixed price contract system. }\end{array}$ & $-0,182$ & 1,140 & 0,255 & Rejected \\
\hline H II & $\begin{array}{l}\text { There is a significant negative effect of the land acquisition risk on the } \\
\text { time performance of a design project with a fixed price contract system. }\end{array}$ & $-0,192$ & 1,234 & 0,218 & Rejected \\
\hline H III & $\begin{array}{l}\text { There is a significant negative effect of the third-party risk on the time } \\
\text { performance of a design project with a fixed price contract system. }\end{array}$ & $-0,117$ & 0,662 & 0,508 & Rejected \\
\hline H IV & $\begin{array}{l}\text { There is a significant negative effect of the utility disruption risk on the } \\
\text { cost performance of a design project with a fixed price contract system. }\end{array}$ & $-0,510$ & 4,579 & 0,000 & Accepted \\
\hline H V & $\begin{array}{l}\text { There is a significant negative effect of the land acquisition risk on the } \\
\text { cost performance of a design project with a fixed price contract system. }\end{array}$ & 0,171 & 1,289 & 0,198 & Rejected \\
\hline H VI & $\begin{array}{l}\text { There is a significant negative effect of the third-party risk on the cost } \\
\text { performance of a design project with a fixed price contract system. }\end{array}$ & $-0,262$ & 2,057 & 0,040 & Accepted \\
\hline H VII & $\begin{array}{l}\text { There is a significant positive effect of the time performance on the cost } \\
\text { performance of a design project with a fixed price contract system. }\end{array}$ & 0,345 & 2,486 & 0,013 & Accepted \\
\hline
\end{tabular}

\section{E. Discussions}

Based on the discussion's result with most of the research respondents and other related parties found that there are several essential findings as follows. First is the effect of the external risk to projects' performance with a fixed price contract system. Based on the quantitative and qualitative data analysis, not all risk variables have a significant effect on project performance, especially to project time performance. Significant negative effects only shown by the utility disruption risk and third-party risk on cost performance, while the positive effect found on the relationship between time performance and cost performance.

In the context of quality performance, it concluded that quality performance is not negotiable. The required specifications must be met because they are related to the heavy construction that will be used by the wider community.

In terms of time performance, majority of the respondents said that it is better to accelerate the implementation time. In other words, after being left behind due to external risk, the pursuit or acceleration of work is the best step. Therefore, additional resources needed that also increased the number of tools, materials, or the number of workers. However, the late completion of work that not caused by the contractor was not subject to a late fee.

Published By: 


\section{External Risk Effect in Infrastructure Design-Build Projects with Lump Sum Contracts}

For cost performance, the acceleration of time completion time also increased the actual projects' cost. In this regard, the general costs and employee costs increase are due to the increase in implementation time. Furthermore, cost increase also caused by idle time because of waiting for the handling of the external risk. Another option was to return the tools, but this option constraint by the additional costs of tools' mobilization and demobilization.

Concerning the transfer of risk or risk sharing, risk sharing is not entirely successful because third parties such as subcontractors or tool providers are not willing to contract at a fixed price where third parties will fully bear the risk. Certain parties choose to get a lower profit opportunity with fewer risks.

The other thing that related to handling external risks is scheduling work. The adjustment of job scheduling needed to synchronize to the risk management schedule in such a way that the effectiveness and efficiency of the work can be maximized by considering all aspects. If the handling of the risks turns out to be a setback, then a new work plan could be made.

Second, the process of change in design and technical engineering. Changes in design caused by several conditions as follows: (a) needs in the field due to utility conditions that not adequately informed at the tender process; (b) design changes due to third-party requests that not included in the initial contract; and (c) design changes due to new technologies that could improve efficiency.

Related to changes that cause cost consequences, a capable and trusted independent checker also needed. Besides, there must be standard procedures for implementing changes from technical studies and commercial studies if needed.

Third, related to job handover. Handover to projects owned by the government must be carried out externally by the Audit Board of Indonesia (BPK). The problem that often arises is the discrepancy between the project design at the tender phase with the as-built drawing. Not all auditors could accept this discrepancy, that changes in drawing/design could occur in design-build projects. Socialization is needed related to the work process of the design project, and then it could be used as an operational standard.

\section{CONCLUSION}

There was no external risk that had a significant effect on time performance. The significant effect showed by utility disruption risk and third-party risk to cost performance, and time performance to cost performance.

There are several recommendations based on this research as follows. First, the project owner must coordinate the risk management in the context of relocation of utility disruption, land acquisition, and handling of third-party risk before the design-build project begun. It is vital to have a fixed price contract system that is fair and balanced.

Second, after the existence of utility disruption risk, land acquisition risk, and third-party risk identified, the schedule for the risk transfer or risk handling must be conveyed before the project begun. Furthermore, the risk handling progress must be informed to the contractor so that further anticipation could be prepared.

Third, after the critical parts of the risk identified, the contractor also advised identifying risks themselves, for instance, by using geo-radar to detect the utility existence or by checking directly the land that has not acquisition. It is needed to get the most efficient technical planning and work method planning.

\section{REFERENCES}

1. Rato, "Evaluasi Penerapan Kontrak Lump Sum dari Sudut Pandang Kontraktor pada Proyek Pembangunan Jalan Tol (Studi Kasus Proyek Pembangunan Jalan Tol Semarang-Banten)," Sekolah Pascasarjana Universitas Muhammadiyah Surakarta, Surakarta, 2018.

2. Project Management Institute, A Guide to the Project Management Body of Knowledge: PMBOK Guide, Newton Square: Project Management Institute, Inc., 2017.

3. T. Alam, "Identifikasi Faktor-Faktor Risiko Proyek Rancang Bangun (Design and Build) pada PT. XYZ yang Berpengaruh terhadap Kinerja Waktu," Fakultas Teknik Universitas Indonesia, Depok, 2011.

4. C. N. Juliana, A. M. Ramirez and B. J. Larkin, Construction Management/Design-Build, 2005.

5. S. M. Seyedhoseini and M. A. Hatefi, "Two-Pillar Risk Management (TPRM): A Generic Project Risk Management Process," Transaction E: Industrial Engineering, vol. 16, no. 2, pp. 138-148, 2009.

6. R. W. Prabawani, "Analisis Dampak Risiko Proyek terhadap Kinerja Proyek (Studi pada Industri Konstruksi di Jawa Tengah Periode Tahun 2001-2010)," Jurnal Bisnis Strategi, vol. 21, no. 2, pp. 79-91, 2012.

7. Project Management Institute, Practice Standard for Project Risk Management, Newtown Square: Project Management Institute, Inc., 2009.

8. P. A. Suwandi, "Kajian Manajemen Risiko pada Proyek dengan Sistem Kontrak Lump Sum dan Sistem Kontrak Unit Price (Studi Kasus pada Proyek Jakan dan Jembatan, Gedung, Bangunan Air)," Magister Teknik Sipil Program Pascasarjana Universitas Diponegoro, Semarang, 2010.

9. The Government of The Republic of Indonesia, Peraturan Presiden Republik Indonesia Nomor 16 Tahun 2018 tentang Pengadaan Barang/Jasa Pemerintah, Jakarta: Ministry of Law and Human Rights Republic of Indonesia, 2018.

10. P. F. Kaming, F. Rahardjo and Y. G. Situmorang, "Analisis KInerja Proyek Konstruksi," in Konferensi Nasional Teknik Sipil 4 (KoNTekS 4), Bali, 2010.

11. H. P. Magaline, A. J. Haryono and Andi, "Survei Mengenai Biaya Overhead serta Faktor yang Mempengaruhinya," Jurnal Dimensi Pratama Teknik Sipil, vol. 4, no. 2, 2015.

\section{AUTHORS PROFILE}

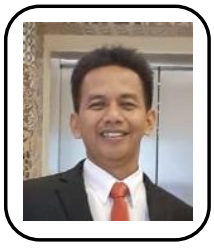

Ari Wibowo, currently he is completing his degree in Civil Engineering Master Program at Mercu Buana University. He already earned a master's degree in Management in 2017 at the same university. His curren job is as a Senior Manager in a construction company, PT Jaya Konstruksi Manggala Pratama, Tbk. He has more than 20 years of experience in infrastructure projects throughout Indonesian areas. There are many infrastructure projects that he had completed, and the most critical projects that he had handled were as follows: Underpass Ciledug, Underpass Matraman, Jalan Layang Trunojoyo, Flyover Surabaya, and Mahakam Bridge in Samarinda City, East Kalimantan Province.

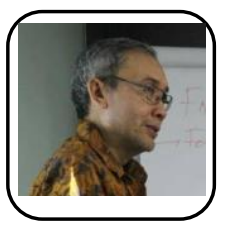

Rosalendro Eddy Nugroho is Assistant Professor at Civil Engineering Master Program in Mercu Buana University, Jakarta, Indonesia. He is also giving a lecture in the Master of Management Program Faculty of Economics and Business in the same university. He graduated from Doctor of Science in Business and Management in the Bogor Institute of Agriculture, Indonesia, in 2013. His doctoral thesis was about "Domestic Factors that Affect the Price of Styrene Butadiene Latex (SBL) in Indonesia. He received a bachelor's degree from undergraduate study program, majored in Chemist at Gadjah Mada University in 1989, and his master's degree in Management from the Satyagama University in 1999. His areas of expertise include investment management, applied mathematics, and operation management.

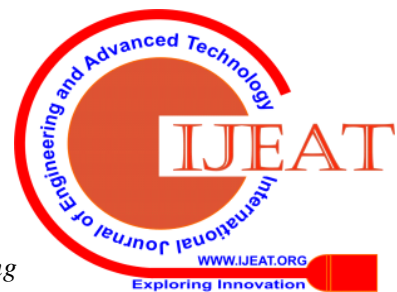


Bambang Purwoko Kusumo Bintoro, currently he is Assistant Professor at Graduate School of Business, Bakrie University. He graduated from Doctor of Science in Management study program of the School of Business and Management in the Bandung Institute of Technology, Indonesia. He received bachelor's degree from undergraduate study program, Civil Engineering Department of the Bandung Institute of Technology on 1982, and his MBA degree from the Marshall Graduate School of Business Administration - University of Southern California, Los Angeles on 1987. His research interests include project management and decision science, especially on the actor's interaction which involved in the project implementations. 